TEME, г. XLIV, бр. 3, јул - септембар 2020, стр. 703-720

\begin{tabular}{lr}
\hline \hline Оригинални научни рад & https://doi.org/10.22190/TEME190304053P \\
Примљено: 4. 3. 2019. & UDK 316.774
\end{tabular}

Ревидирана верзија: 13. 9. 2020.

Одобрено за штампу: 1. 10. 2020.

\title{
КОНЦЕПТ ПОЈЕДИНЦА У ЛИЧНИМ ОГЛАСИМА ЗА УПОЗНАВАЊЕ У СРПСКИМ И НЕМАЧКИМ МЕДИЈИМА - УПОРЕДНА АНАЛИЗА ДРУШТВЕНИХ ВРЕДНОСТИ
}

\author{
Нина Половина \\ Универзитет у Београду, Саобраћајни факултет, Београд, Србија \\ n.polovina@sf.bg.ac.rs
}

\begin{abstract}
Апстракт
У раду се истражује концепт појединца који се конструише кроз личне огласе објављене у српским и немачким штампаним и електронским медијима. Подлогу истраживања чине досадашња испитивања доминантних вредности, а узима се у обзир и начин реализације очекивања које појединац исказује у односу на потенцијалног партнера. Вредности, као апстрактне категорије, чине основу практичног делања појединца, а истовремено представљају показатеље доминантних друштвених ставова. У сврху истраживања корпуса примењени су упоредни метод, анализа садржаја и статистичка анализа како би се утврдиле културолошке сличности и разлике, с једне стране, али и типични концепти мушкараца и жена, с друге стране. Резултати су показали да постоје одређене разлике у концептима појединаца у српским и немачким огласима, које су засноване на другачијим вредносним оријентацијама друштава, али и да постоје одступања у формирању концепта у зависности од родних карактеристика емитента или реципијента.
\end{abstract}

Кључне речи: анализа садржаја, лични огласи, партнерство, појединац, штампани и електронски медији.

\section{THE CONCEPT OF THE INDIVIDUAL IN PERSONAL DATING ADS IN PRINT AND ELECTRONIC MEDIA - COMPARATIVE STUDY OF SOCIAL VALUES}

\begin{abstract}
This paper studies the concept of the individual occurring in personal dating ads published in Serbian and German print and electronic media. The research is based upon existing studies of dominant values, but takes into account the fulfillment of an individual's expectations vis-à-vis her/his potential partner as well. The values, as abstract categories, represent the basis for the very process of creating an ad by its author, while at the same time they are indicators of the dominant social attitudes. By applying the method of contrastive, content and statistical analysis, culture-based similarities and differences, as well as the typical concepts of men and women have been determined. The results of the
\end{abstract}


704

study show that there occur, in fact, certain differences in the concept of the individual in Serbian and German ads. These originate from different values and orientations of the two societies. On the other hand, some discrepancies are sex-related.

Key words: content analysis, individual, partnership, personal dating ad, print and electronic media.

\section{УВОД}

Истраживања културних и друштвених феномена често се везују за вредности, узимајући их као основну категорију, темељ, односно исходишну тачку, у реализацији културног обрасца (уп. Hofstede, 2001; Schwartz, 1994; Inglehart, 1998; Kluckhohn \& Strodtbeck, 1961; Rokeach, 1976; Пантић, 1981; Бешић, 2014а; Павловић, 2006; Kraemer, 1998). С обзиром на то да се ради о апстрактним конструктима, постоје разни покушаји дефинисања овог појма, па их Хофстеде (Hofstede, 2001, стр. 5) описује као срж саме културе, тенденције да се да̂ предност одређеном стању ствари у односу на неко друго, Шварц наводи да су вредности културни идеали (Schwartz, 2004, стр. 43), те да имају улогу водећих принципа које појединци или групе когнитивно обликују како би били у стању да објасне, координишу и рационализују своје понашање (Schwartz, 1996, стр. 4), Пантић (Пантић 1981, стр. 13) истиче њихову општост, хијерархијску уређеност и релативну стабилност, Клакхон (Kluckhohn \& Strodtbeck 1961) наглашава пожељност као критеријум који се узима у обзир приликом одабира, а Кремер их дефинише као оријентационе смернице које имају социјалноинтегративну функцију (Kraemer, 1998, стр. 77). У раду се полази од овог обједињеног поимања вредности, па се оне посматрају као специфично уређена „скала” која у неком друштву прописује или предлаже матрицу понашања, делања и размишљања. На овај начин структурисан(и) вредносни систем у непосредној је вези с појединцем, чинећи оквир његовој иновативности (Бешић 2014б, стр. 17), јер су структура и појединац који у њој дела међусобно повезани, па делање појединаца током времена доводи и до измена у структури (Гиденс, цит. према: Рицер 2012, стр. 276).

Основни проблем приликом утврђивања које су вредности доминантне у друштву је у томе што их није могуће проучавати директно, али се суд о њима може формирати на основу културних производа, односно манифестација у које су утиснуте. За потребе овог рада као полазиште су коришћени резултати компаративног истраживања које је обавио Хофстеде, студије GLOBE и European Values Study (уп. Hofstede, 2001; House, Hanges, Javidan, Dorfman \& Gupta, 2004; European Values Study) и радови Бешића, Павловића, те Вукоњанске и сарадника (Бешић, 2014а; Бешић, 2014б; Павловић, 2006; Vukonjanski, Nikolić, Hadžić, Terek \& Nedeljković, 2012), при 
чему су узети у обзир подаци за Србију и Немачку како би се могло обавити поређење. Резултати наведених истраживања указују на то да су у српском друштву, у односу на немачко, израженије материјалистичке вредности ${ }^{1}$, традиционализам, потреба за избегавањем неизвесности, тешко прихватање промена, потреба за ауторитетом и хијерархијом. У немачком друштву доминантније су постматеријалистичке вредности, наглашена је индивидуализација (као отклон од традиционалног - уп. Beck, 1986), остваривање сопствених жеља, достизање среће и уживање.

\section{ЛИЧНИ ОГЛАСИ}

Лични огласи су део друштвене стварности - јавне објаве које емитенти формирају како би пронашли адекватног партнера. Овако јасно дефинисана сврха чини личне огласе директним медијумом у успостављању контакта између потенцијалних партнера, док су, с друге стране, и медијум у симболичком смислу, јер преносе слику коју појединац ствара о себи или потенцијалном партнеру. Како би до те слике дошло, емитент је принуђен да јавно изнесе извесне личне информације да би створио практичне и реалне претпоставке за комуникацију.

Специфичност комуникације у личним огласима огледа се у томе што се на почетку износе како елементи спољног слоја ${ }^{2}$ (нпр. изглед) тако и неки елементи унутрашњег слоја (нпр. надања, циљеви) (Carpenter \& Greene, 2016), док у личним контактима постоји градација интимности и постепеност у откривању информација (уп. Altman \& Taylor, 1973; Riemann, 1999). Стога одабир конкретних података који се износе у личним огласима никако није случајан, већ је резултат стратегије, јер се истицањем одређених чињеница, а прикривањем других - ствара идеализован утисак (Гофман, 2000, стр. 76; Ellison, Heino \& Gibbs, 2006, стр. 426). Избор стратегије откривања себе (кроз слику себе или потенцијалног партнера) обавља се на основу искуства и у односу на замишљену будућу интеракцију (нпр. тип везе) (Gibbs et. al., 2006; Walther 1996), а у корелацији је с менаџментом импресије (Гофман, 2000). Емитенту је циљ да се прикаже у позитивном светлу (пожељна особа) како би постигао сврху сопственог

\footnotetext{
${ }^{1} \mathrm{O}$ разликовању материјалистичких и постматеријалистичких вредности може се пронаћи више код Бешић, 2014б и Ingelhart 1998.

${ }^{2}$ Слојевитост комуникације приказана је на основу теорије социјалне пенетрације, према којој људи у интеракцији и размени информација постепено откривају све дубље слојеве, од оних спољних, преко средњих и унутрашњих, па све до суштинских карактеристика личности (уп. Carpenter \& Greene, 2016; Altman \& Taylor, 1973).
} 
оглашавања (проналажење партнера), у сагласју с друштвеним нормама и очекивањима, јер свакодневица израста из сфере приватног, али је неминовно под утицајем вредносних канона које поставља само друштво (Heinemann, 2000, стр. 605).

Селекција података претвара личне огласе у рекламе оглашивача, истичући управо оно што ће код прималаца изазвати најбољи ефекат, а конкретно реализован приказ емитента и/или потенцијалног партнера у таквој ситуацији изгледа као једини могућ. Другим речима, емитент бира „маску” (вербализовану слику себе и/или партнера) коју ће кроз свој „наступ” (лични оглас) да прикаже публици (Гофман, 2000). У Гофмановој терминологији лични односи представљају предњу зону, оно видљиво и очигледно где се појединац приказује другима, уз свест о утиску који притом изазива (Гофман 2000, стр. 149 и 236).

\section{ОЧЕКИВАҢА ОД ПАРТНЕРА}

Кад се ради о партнерским односима у личним огласима, начин представљања полова одражава конвенционалне и уврежене приказе мушкараца и жена, дакле социолошко-културолошки став самог друштва, односно улоге и (родне) идентитете унапред додељене мушкарцу и жени на основу доминантних вредносних схватања (Goffman, 1981, стр. 10; Гофман, 2009, стр. 14; Whitty, 2007, стр. 60). Дакле, вредносни канони утичу на дефинисање личних улога (и њихово редефинисање током времена, у складу с померањем вредности и променама у друштву), али и на модификовање породичних односа и партнерства, па се различита очекивања од партнера (нпр. у домену изгледа или типа везе) посматрају као индикатор степена развоја друштва, његове претежно материјалистичке или доминантно постматеријалистичке оријентације (Ingelhart, 1998; Бобић, 2010; Бауман, 2009).

Приликом контакта с потенцијалним партнером, појединац несвесно износи став друштва, а у суштини се понаша и приказује онако како мисли да се од њега очекује. Овакав концепт Гофман назива очекивање очекиваног (Goffman, 1994), а он се своди на релативно једноставну комуникациону технику уграђивања очекивања других у сопствено понашање или приказивање. Риман (Riemann, 1999, стр. 32) истиче да се оваква особина људске комуникације своди на жељу за изазивањем максимално позитивног утиска, те да човек кроз очекивања од потенцијалног партнера антиципира његове евентуалне реакције, те норме и вредности које он сматра важним. Како би реакција реципијената била адекватна, потребно је да постоји извесна симетрија у приказу сопствене личности и потраживању од партнеpa, јер се кроз идеал другога ствара назнака очекивања, која прона- 
лази одраз у приказу себе, тј. „мој сопствени пламен проналази свој блештави одсјај ... мој вољени може бити билборд на коме је насликана моја савршеност у свој својој величанствености и сјају" (Бауман, 2009, стр. 34).

Ми, као појединци, имамо одређене представе о исправном или жељеном понашању, па их несвесно трансформишемо у нормативна очекивања која утискујемо у своје делање и тражимо у другима, стварајући на тај начин виртуелни друштвени идентитет. Тај идентитет ствара се кроз склоп категорија и карактеристика које емитент, поштујући друштвене оквире, утискује у вербални израз (лични оглас) (Гофман, 2009). На његово обликовање утичу бројни „спољни” фактори, а појединац за различите прилике може да створи засебне идентитете. Раскорак између виртуелног и стварног друштвеног идентитета у оваквом истраживању није могуће утврдити, али и само постојање потребе за стварањем виртуелног идентитета указује на то да појединац дела у складу с имплицитно усвојеним шаблонима друштва, трудећи се да испуни очекивања.

\section{МЕТОДОЛОГИЈА ИСТРАЖИВАЬА}

Примарни методолошки поступак у раду јесте упоредни метод, који се примењује с циљем утврђивања сличности и разлика у корпусном материјалу и вредносним комплексима који се кроз њега очитују. Други значајан метод који се користи је анализа садржаја метод погодан за проучавање великог броја података присутних у огласима. Трећи методолошки поступак чини статистичка анализа учесталости по различитим основама, да би се утврдиле доминантне тенденције.

Како би истраживање пружило основу за адекватно културолошко поређење, концепт појединца дат је на основу свих личних огласа објављених у истом периоду у српским и немачким штампаним и електронским медијима ${ }^{3}$.

\footnotetext{
${ }^{3}$ Истраживање је обухватило све личне огласе објављене једног викенда у августу и септембру 2015, 2016. и 2017. године у српској штампи (националне дневне новине Политика и Вечерње новости, регионалне дневне новине Дневник и огласник Хало огласи), немачкој штампи (надрегионалне дневне новине Frankfurter Allgemeine Zeitung и Süddeutsche Zeitung, регионалне дневне новине Kölner Stadt-Anzeiger и Sächsische Zeitung) и на интернет порталима отвореног типа (www.markt.de, www.serbiancafe.com). Конкретне новине одабране су поштујући принцип паритета, у мери у којој је то било могуће спровести. Наиме, потешкоћу приликом одабира корпуса представљала је чињеница да се категоризација новина у овим земљама не обавља на исти начин (нпр. у Србији не постоје надрегионалне дневне новине, али једнаку распрострањеност и значај имају националне дневне новине). У недостатку већег броја регионалних новина у
} 


\section{ИСТРАЖИВАЊЕ КОНЦЕПТА ПОЈЕДИНЦА У ЛИЧНИМ ОГЛАСИМА}

Лични оглас у структурном смислу садржи више елемената који у симбиози стварају слику појединца. Било да се ради о његовом дефинисању, опису или карактеристикама, пажљивим одабиром емитент као учесник у комуникацији ствара јединствену маску (Гофман 2000), кроз коју посредно указује на естетске, вредносне и друге каноне који су доминантни и/или пожељни у друштву. Имајући то у виду, у овом истраживању не раздвајају се анализе емитента и партнера, понуда и потражња у огласима, директан и индиректан приказ, јер конкретан концепт који се кроз оглас конфигурише одражава појединца као типичног припадника одређеног културног и друштвеног окружења.

Тако конципирана анализа обухватила је 5 елемената:

1. начин дефинисања појединца;

2. старост;

3. изглед;

4. друштвени положај;

5. карактеристике.

\section{1. Дефинисање појединияа}

За дефинисање појединца на располагању је читав дијапазон могућности - од прономиналног облика у номинативу или акузативу (ja/ich, meбe/dich), преко неутралног 3. лица једнине у номинативу или акузативу (он-она/er-sie, юb-њьеza/ihn-sie), па до коришћења полних ознака, статуса, занимања, националности, година, хороскопских знакова и других одредница које оглашивач доживљава као информације од посебног значаја. Дефинисање партнера/партнерке обавља се с циљем усмеравања публике, па може да ограничи круг потенцијалних реципијената или да садржи општије наводе како би се што већи број реципијената у њима препознао. Овај елемент стоји на почетку огласа, а ради се о оном делу личности који емитент жели да истакне као посебно значајан.

Србији и узимајући у обзир културолошки специфичне разлике у навикама оглашивача, у корпусни материјал уврштене су и српске огласне новине, које редовно објављују огласе овог типа. Овако конципираним одабиром, корпусни материјал обухватио је 58 огласа из српских штампаних медија и 203 огласа из електронских, те 895 немачких штампаних огласа и 1022 огласа из електронских медија. Конкретне разлоге за значајно већи број огласа у немачким изворима овим истраживањем није могуће утврдити, али се то доводи у везу с бројем становника, конкурентношћу тржишта, тиражем новина и навикама читалаца. 


\section{1. Српски огласни корпус}

У српским огласима оглашивачи дефинишу себе: наглашавањем пола (момак, дама), порекла или места становања (Београђанин, Бањалучанка), брачног стања (самац, удовица) и занимања (пензионер, адвокат). Партнер се најчешће дефинише као господин, мушкараи или момак, а код женског пола дама, жена и девојка. Занимљиво је да има огласа у којима се тражи Српкиња, дакле, особа прецизно дефинисана националношћу, али с друге стране и огласа који при дефинисању партнера не постављају никаква ограничења. Занимљиво је поменути да су мушки оглашивачи више усмерени на истицање занимања, док женски радије користе неутралније полне ознаке.

\section{2. Немачки огласни корпус}

Немачки лични огласи дефинисање појединца обављају користећи знатно већи варијетет језичког материјала. Дефинисање оглашивача одвија се кроз истицање пола (Mann [мушкараи], Daтe [жена, госпођа]), порекла или места становања (Münchner [становник Минхена]), брачног стања (Junggeselle [неожењен мушкараи]) или занимања (Tierärztin [ветеринарка]), затим навођењем година, личних имена, прономиналним облицима (ich [ja], er [oн], sie [oнa]), потом припадношћу хороскопском знаку и употребом метафора. Најчешће коришћен израз код дефинисања партнера код оба пола је Partner/-in [партнер/-ка], а потом следе изрази Maпn [мушкараи] и Fraи [же$н a]$, те личне заменице за 2. или 3. лице једнине у акузативу или номинативу $\mathrm{Dich} / \mathrm{Du}[\mathrm{Te \sigma e} / \mathrm{Tu}], \mathrm{Ihn} / \mathrm{Er}\left[\right.$ [Њега, Oн], Sie [Њу/Oна] ${ }^{4}$, које су готово доследно писане великим словом. Дефинисање је код оба пола, за разлику од српског корпуса, више усмерено ка коришћењу неутралних заменичких форми или полних ознака, док се истицање занимања налази тек на трећем месту према учесталости.

\section{3. Анализа}

Дефинисање личности у српским изворима чешће се одвија кроз истицање порекла или места становања као практичне информације за успостављање везе или коришћењем неутралних категориja, а у суштини је прилично једнообразно. Недостатак инвентивности овде се своди на традиционалистички приступ и удовољавање захтевима публике, која у овој текстуалној форми и не очекује нешто другачије. Немачким друштвом доминира индивидуализам и појединци се лакше прилагођавају промени места боравка, па истицање порекла или пребивалишта није учестало коришћен податак. Овде се

\footnotetext{
${ }^{4}$ Нпр. Ich suche Dich [Ја тражим Тебе], Er sucht Sie/Ihn [Он тражи Њу/Њега]
} 
чешће користе необични описи (нпр. Mittelalter Topf sucht Deckelchen [Лонаи средњих година тражи поклопаи]), који су одговор друштва на растућу усамљеност и отуђеност појединца у модерном друштву, што неминовно води ка адаптацији техника привлачења пажње и даљем развијању менаџмента импресије.

\section{Cmapocm}

Старост је овде потребно сагледати двојако: с једне стране су то године оглашивача, а с друге тражене године потенцијалног партнера. Подаци о годинама наводе се с циљем селектовања публике могу да буду исказани тачно или оквирно 5 (нпр. између 40 и 50 година), а понекад стоји само назнака да се тражи особа сличних година, да су године небитне и сл.

Табела 1. Учесталост истицања година у личним огласима

\begin{tabular}{lcccc}
\hline Медији & \multicolumn{2}{c}{$\begin{array}{c}\text { Учесталост навођења } \\
\text { година оглашивача }\end{array}$} & \multicolumn{2}{c}{$\begin{array}{c}\text { Учесталост навођења } \\
\text { година партнера }\end{array}$} \\
\cline { 2 - 5 } & Мушкарци & Жене & Мушкарци & Жене \\
\hline Српски медији & $60,3 \%$ & $80 \%$ & $45,9 \%$ & $80 \%$ \\
Немачки медији & $89,1 \%$ & $91,5 \%$ & $26,2 \%$ & $40,8 \%$ \\
\hline
\end{tabular}

Код података о годинама оглашивача културолошки се не примећују значајније разлике, али се код информација о партнеру истиче готово двоструко чешће навођење у српским медијима. Разлози такве праксе могу да буду избирљивост продуцената огласа као одраз очекивања друштва или практичан приступ услед којег оглашивачи не желе да губе време на неадекватне реципијенте. С друге стране, потпуно је очигледно да мушкарци у обе земље ређе истичу године у својим огласима, поготово кад се ради о њиховим партнеркама, а да је женама старост много значајнија категорија ${ }^{6}$.

\section{1. Српски огласни корпус}

Анализа старосне структуре показује да просечан оглашивач има 44,2 године (мушки оглашивач 47,9, а женски 40,5 година). С обзиром на два истражена медија, треба нагласити да просечан аутор огласа објављених у штампи има 50,2 године, а на интернету 38,2 године. Упадљива разлика у годинама у односу на медиј указује на

\footnotetext{
${ }^{5}$ Ако је старост партнера наведена оквирно (нпр. 40-50 година), приликом рачунања просечне старости узета је средња вредност постављеног оквира.

${ }^{6}$ Било би занимљиво накнадно истражити због чега жене придају толико пажње годинама - да ли се ради о доживљају пролазне лепоте, о откуцавању биолошког сата или су у питању други разлози.
} 
учесталост коришћења интернета међу млађом популацијом у Србији. Просечан партнер има готово исто година колико и оглашивач - 44,4 (46,4 године партнерка и 42,5 година партнер). Медијски условљена разлика и овде је приметна: пожељан партнер у штампи имао би просечно 48,2 године, а на интернету 40,6 година.

\section{2. Немачки огласни корпус}

У немачким личним огласима просечан оглашивач има 48,3 године (у штампаним медијима 53,3, а у електронским 43,3), а разложено према половима, просечан мушки аутор има 47,5 година, а женски 49,1 годину. Просечан партнер требало би да има 43,4 године; партнерка коју траже мушки оглашивачи 38,6 година, а партнер којег би жене волеле да имају 45,3 године. Засебно истраживање огласа према коришћеним медијима показало је да би пожељан партнер, односно пожељна партнерка, који/која се тражи путем штампаних медија требало да има 48,6 година, док би идеалан партнер, односно идеална партнерка, до кога/које се долази преко интернета требало да има 38,3 године.

\section{3. Анализа}

Поређење огласа показало је да су емитенти огласа, без обзира на пол, најчешће у четрдесетим годинама, а да таква очекивања имају и од партнера, уз незнатне варијације ${ }^{7}$. Медијско диференцирање прилично је уједначено према културама и половима, те се уопштено може да рећи да су у штампаним медијима обично активни појединци у четрдесетим или педесетим годинама, док су у електронским медијима заступљеније нешто млађе генерације.

Поређење старосне структуре српских и немачких појединаца у личним огласима открива да се ради о истој популационој групи, jep је просечан аутор/партнер огласа ${ }^{8}$ у Србији стар око 44 године, а у Немачкој око 46 година. Разлике у погледу старости мушкараца и жена као оглашивача или партнера прилично су мале, па можемо да кажемо да стереотипи о очекивању полова у вези с годинама нису експлицитно изражени.

\footnotetext{
7 Овакве резултате, с једне стране, треба узети с резервом, јер су закључци, из објективних разлога, изведени само на основу огласа који имају квантификован податак о годинама. С друге стране, сведена форма личних огласа подразумева истицање управо оних елемената за које емитенти сматрају да су од кључног значаја, па оваква анализа старости представља солидну подлогу за извођење закључака.

${ }^{8}$ Овде су наведене просечне вредности добијене на основу претходних резултата
} 


\section{3. Изглед}

Изглед појединца у личним огласима у непосредној је вези с друштвеном стварношћу, па се остварене естетске категорије своде на удовољавање очекивањима реципијента, односно друштва. Како би се сумирала ${ }^{9}$ слика пожељног појединца у одређеној култури и одређеном друштву, анализа је обухватила најчешће наводе у домену спољашњег изгледа.

\section{1. Српски огласни корпус}

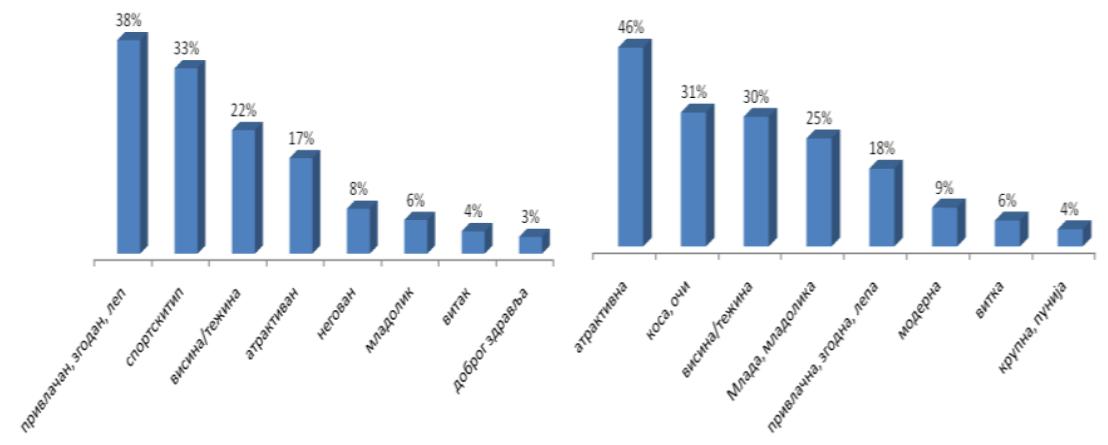

Слика 1. Наводи о изгледу мушкария у српским огласима

Слика 2. Наводи о изгледу жене у српским огласима

\section{2. Немачки огласни корпус}

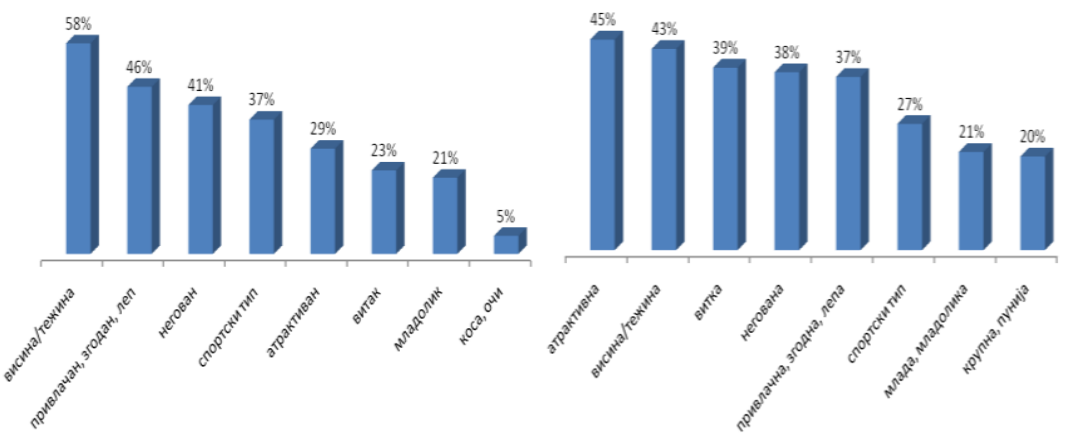

Слика 3. Наводи о изгледу мушкариа Слика 4. Наводи о изгледу жене у немачким огласима у немачким огласима

${ }^{9} \mathrm{C}$ обзиром на то да се ради о језички разноврсним наводима, пре саме анализе обављено је семантичко груписање како би се под једну одредницу подвели елементи истог или сличног денотативног, али и конотативног значења - нпр. изрази groß [крупна], mollig [пунија], weibliche Figur [женствена фигура] подведени су под категорију пунија, а привлачне спољашњости, привлачан, леп под категорију привлачан, згодан, леп, док се слична категорија атрактиван односи и на наводе типа секси, заводљив, који имају другачију конотацију. 


\section{3. Анализа}

Естетски концепт мушкарца у Србији и Немачкој је веома сличан, па се примарно очекује да су привлачни, спортски типови, атрактивни, неговани и младолики. Код жена се, осим категорија атрактивна, привлачна, негована, које се према учесталости готово поклапају у оба корпуса, у немачком истичу и витке, али и пуније жене. У истом корпусу приметно је и очекивање да је жена спортски mun, што је незабележено у српској варијанти. Овакви поступци сведоче о значајније заступљеним постмодерним вредностима у немачком друштву, јер естетски приказ жене излази из оквира традиционалних родних очекивања и указује на равноправност чак и у домену који је примарно резервисан за мушкарце. Осим тога, бављење спортом наглашава окретање (жена) сопственим задовољствима и циљевима, као назнаке израженијег индивидуализма. С друге стране је занимљиво поменути да у српским огласима изглед није с толиком учесталошћу приказан у првом плану, па би на основу тога могло да се закључи да емитенти његово истицање не оцењују као потребно или примерено ${ }^{10}$. Кад се посматрају разлике у понашању полова, приметна је тенденција жена (у оба друштва) да дају више података о сопственом изгледу, а мање података о конкретном изгледу какав очекују од партнера.

Занимљиво је нагласити да се скуп физичких манифестација које оглашивач наводи о себи готово савршено уклапа са скупом карактеристика које се од њега као партнера очекују; другим речима, жене себе, као оглашивачи, приказују управо онако како их желе мушкарци као партнерке! И обратно, мушкарци раде исто то. Дакле, апсолутно може да се каже да се „очекивање очекиваног” примењује у огласном дискурсу.

\section{4. Друштвени положај}

С обзиром на специфичност истраживања, друштвени положај појединца је проучен поједностављено, кроз две од његове три димензије: економски и културни капитал, јер указивање на политички капитал није присутно у огласном регистру (Лазић \& Цвејић, 2004, стр. 45). Економска димензија најчешће се огледа кроз информације о финансијској ситуацији или професији, а на културни капитал указују подаци о образовању.

\footnotetext{
10 Овакав закључак представља претпоставку засновану на културолошким истраживањима која чине темељ овог рада, док би конкретни разлози за такву праксу оглашавања могли да се утврде само испитивањем ставова емитената, што превазилази оквире овог рада.
} 


\section{1. Српски огласни корпус}

У српским огласима друштвени положај чешће помињу мушкарци (4-5 пута више него жене), при чему наводе своју професију и/или финансијско стање (пензионер, ситуиран, стамбено и материјално обезбеђен), док жене ређе дају податке о томе или их ограничавају на истицање занимања односно чињенице о (не)запослености, а више истичу брачно стање (разведена, слободна). Кад се ради о очекивањима од партнера, мушкарци ретко постављају очекивања пред своје партнерке, у смислу њене позиције на друштвеној лествици, већ је тежиште огласа стављено на друге елементе, као што је истицање пожељног изгледа. Жене, с друге стране, наводе како од будућег партнера очекују да буде ситуиран, интелектуалаи или успешан, делимично зато што у огласима истичу како су и саме такве, а делимично зато што њихова ситуација захтева да пронађу некога ко ће у социјалном смислу преузети бригу о њима ${ }^{11}$. На такав закључак указују и наводи повратник или живи у иностранству, које жене повремено користе за тражене партнере, алудирајући притом на имућне и добро ситуиране мушкарце или на жељу за пресељењем у иностранство с циљем решавања економског статуса ${ }^{12}$.

\section{2. Немачки огласни корпус}

У немачким огласима на друштвени положај указује се нешто неутралнијим изразима erfolgreich [усnешан], gebildet [образован], при чему нема приметне разлике у половима, што указује на напредак друштва у правцу модернизације и родне равноправности. Осим тога, често се то чини уз другачију намеру, као наговештај да је дотични појединац финансијски стабилан и задовољан, те може своју енергију да усмери на друге сегменте живота. На овакав закључак наводи нас комбинација података о економском статусу и интересовањима која одређују стил живота појединца. Брачно стање се не наглашава сувише често и релативно је равномерно подељено према половима, а доминирају getrennt lebend [растављен], geschieden [разведен/разведена] и verwitwet [yдоваи/удовица]. Очекивања мушкараца од партнерки и овде се крећу у домену других категорија (изглед, карактеристике), док жене повремено наводе изразе који указују на партнерову претпостављену стабилну позицију у друштву (нпр. beruflich situiert [пословно ситуиран], finanziell selbständig [фи-

\footnotetext{
${ }^{11}$ Различите праксе у оглашавању мушкараца и жена у складу су с резултатима Хофстедеовог истраживања и студије GLOBE, који указују на тенденцију доминације мушкараца у српском друштву.

12 Огласи који истичу жељу за пресељењем у иностранство су у немачком корпусу веома ретки (мање од $1 \%$ огласа).
} 
нансијски независтан]) или ниво образовања (нпр. gebildet [образован], Akademiker [академски грађанин]), а индиректно тако поручују да би мушкарац требало да је у стању да им пружи живот који је испуњен и у личном смислу, а не само у материјалном. Немачким личним огласима доминирају очекивања од партнера која не наглашавају друштвени положај, већ у први план стављају особине, животне ставове, интересовања и др.

\section{3. Анализа}

Тумачење овог елемента огласног дискурса неминовно је упућено на сагледавање целокупне друштвене ситуације. У Србији кроз огласни регистар провејава усмереност ка материјалној ситуацији у друштву, упућеност на конкретне прилике и решавање егзистенцијалних питања, па се избор партнера неминовно своди на комбиновање практичних околности и личних избора. Кроз стварање подељене слике, с једне стране, успешних и ситуираних мушкараца, а с друге стране жена које траже успешне партнере, јер себи нису успеле да обезбеде материјалну сигурност - исказује се постојећа неравноправност. Осим тога, значај који се придаје економској димензији показатељ је доминантних материјалистичких вредности. У немачким огласима преовлађују постмодерне вредности, оријентација појединца на себе и задовољавање сопствених потреба. Жене не објављују огласе са циљем достизања материјалне сигурности или решавања питања опстанка, већ им је намера да остваре неке секундарне потребе - индивидуалне, усмерене на лично задовољство и срећу. Разлика у приказу жена у српском и немачком друштву упућује на постојање значајно различитих друштвених пракси.

\section{5. Карактеристике}

Карактеристике су категорија о којој и мушкарци и жене истичу највећи број података и она обухвата прилично разнолике наводе ${ }^{13}$. С обзиром на то да се ради о описним категоријама, те да их има много, овде ће бити наведене само најчешће заступљене, и то у систематизованом виду.

\footnotetext{
13 У ову категорију убројани су веома разноврсни подаци - од карактерних особина до одређених навика - све оно што је део концепта личности, што појединац сматра да треба посебно да истакне, што сматра неизоставним делом свог наступа (или делом партнерове личности) у смислу селективног одабира података или менаџмента импресије (Gibbs, Ellison \& Heino 2006, Гофман 2000).
} 
5.1. Српски огласни корпус

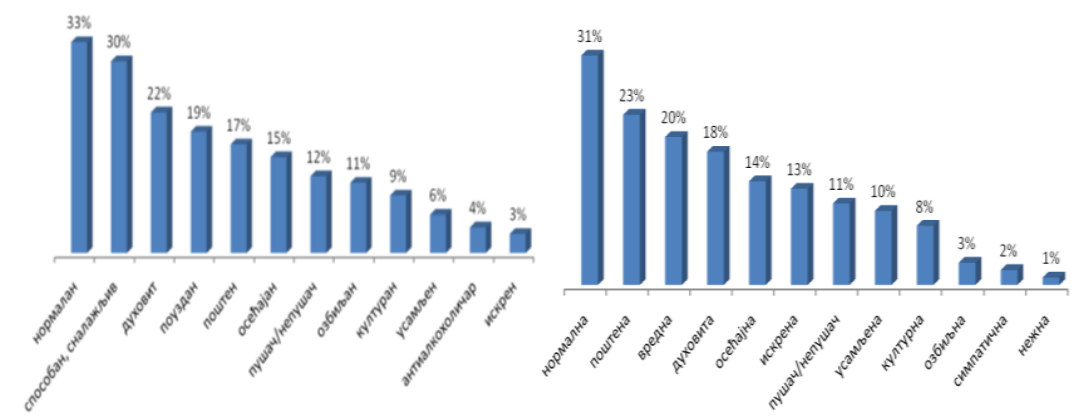

Слика 5. Наводи о карактеристикама Слика 6. Наводи о карактеристикама мушкариа у српским огласима жене у српским огласима

5.2. Немачки огласни корпус

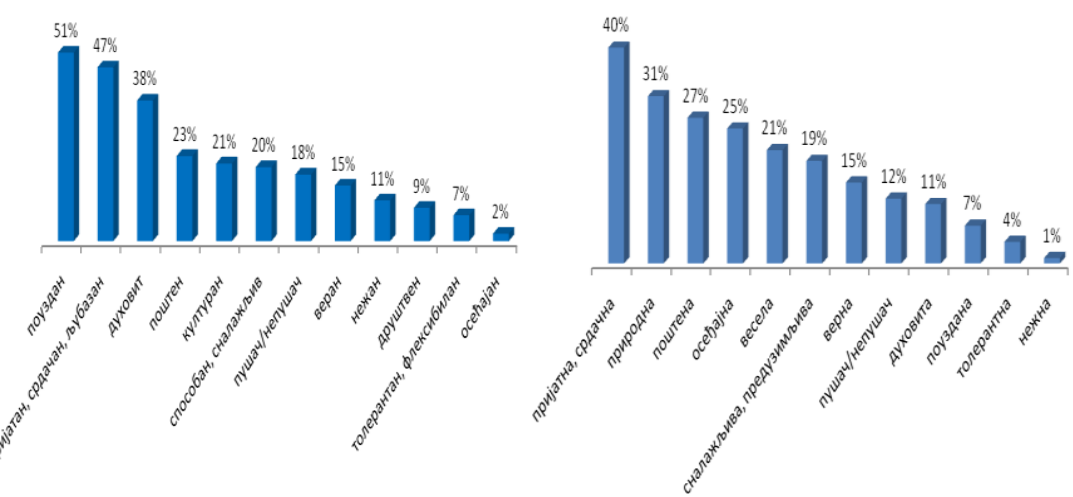

Слика 7. Наводи о карактеристикама Слика 8. Наводи о карактеристикама мушкариа у немачким огласима жене у немачким огласима

\section{3. Анализа}

Кад се погледају подаци о идеалном појединцу у Србији, одмах се уочава да огласним дискурсом доминира захтев да особа буде нормална, без обзира на то о ком полу се ради. Наглашавање овога указује на то колико прилике у земљи могу да буду аномичне, људски односи поремећени, а свакодневица неорганизована, да главна особина на којој се инсистира постане нормалност - нешто што би требало да се подразумева. Наведено указује на то у којој мери се криза друштва пресликава и на кризу међуљудских односа. Мушкарац би, одмах потом, требало да је сналажљив и способан, а жена поштена. У списку особина код оба пола следе духовитост и осећајност. Занимљиво је истаћи да се озбиљност и искреност као наводи појављују само у српском корпусу, указујући на значајне осо- 
бине у тој култури, потребу за (традиционално обојеним) наглашавањем исправне личности, снажног карактера или општељудских врлина. У том смислу треба тумачити и често истицање српске жене као вредне. С друге стране, мушкарци су у оба корпуса наглашено поуздани, што је уобичајено родно специфично очекивање, без разлике у културном миљеу. Истраживање немачког корпуса показало је да оба пола велик значај придају пријатним, љубазним појединцима, док се те особине у српским огласима и не помињу. Поштење је високо котирано код оба пола и у обе културе, а наглашавање тога свакако је у вези са специфичном формом неличне комуникације у личним огласима. Напоменула бих и да се сналажљивост очекује и од мушкараца и од жена у Немачкој, док је у Србији она потребна само мушкарцима, а од жене се та врста активизма не очекује. Поређење је показало како родне разлике (нпр. поуздани мушкарци) тако и разлике у карактеристикама које се потенцирају у дотичном друштву (нпр. нормални појединци у Србији) - што је у складу с полазним истраживањима доминантних вредности у друштву.

\section{ЗАКљУЧАК}

Анализа личних огласа показала је да постоје значајне културолошке разлике између српског и немачког друштва - док је немачко друштво значајније одмакло у процесу трансформације партнерства, промовисању индивидуалних и постмодерних вредности, усмерености ка остварењу личних потреба и достизању индивидуалне среће, српско друштво је још увек подељено између тенденције задржавања традиционалних модела и тежње ка модернизацији - појединци су оптерећени социјалним и материјалним проблемима, а њихови ставови и тежње најчешће се крећу у оквиру уврежених културних норми, при чему се примећује утицај традиције, али и повремено наглашавање постмодерних идеала. Сегментовање корпусног материјала према полу указало је на то да се идентитети појединаца граде на различитим елементима, уз значајно наглашавање разлике између концепта жене и мушкарца. Док немачким огласима доминирају слике мушкараца и жена уз висок степен равноправности исказан кроз естетске доживљаје, друштвени положај и карактеристике, у српским је приметна родна диференцијација, која се манифестује другачијим пожељним категоријама код мушкараца и жена у правцу испуњавања традиционалних очекивања, што је у складу с владајућим нормативним поретком у друштву.

Концепт појединца који се конфигурише кроз личне огласе заснован је на доминантним вредностима, а можемо га посматрати као листу жеља типичну за неко друштво или пажљиво обликован виртуелни идентитет, чије проучавање указује на социјално нормиране 
конструкте и конкретну друштвену стварност у Србији и Немачкој. Истраживање личних огласа показало је да су они адекватан материјал за изучавање друштвених токова и да представљају занимљиво огледало друштва.

\section{ЛИТЕРАТУРА}

Altman, I., \& Taylor, D. (1973). Social penetration: The development of interpersonal relationships. New York, NY: Holt.

Бауман, 3. (2009). Флуидна љубав. О крхкости људских веза [Liquid love. On the Frailty of Human Bonds], Нови Сад: Mediterran publishing.

Beck, U. (1986): Risikogesellschaft. Frankfurt a.M.: Suhrkamp.

Бешић, М. (2014a). Вредносне оријентације у бившој Југославији [Value orientations in countries of former Yugoslavia]. Социолоики преглед, vol. 48, бр. 1, 17-40.

Бешић, М. (2014б). Транзиционе трауме и промене вредносних оријентација генерацијски приступ. Студија вредности у земљама бивше Југославије. [Transitional traumas and changes in value orientations - generational approach. A study of values in the countries of the former Yugoslavia]. Београд: Факултет политичких наука, Универзитет у Београду

Бобић, М. (2010). Партнерство као породични подсистем [Partnership as a family subsystem]. У: Милић, А. и др. (ур.), Време породица. Социолошка студија о породичној трансформацији у савременој Србији (The Time of the Families: Sociological Study of the Transformation of the Family in Present-day Serbia). Београд: Филозофски факултет, 115-145.

Carpenter, A., \& Greene, K. (2016). Social penetration theory. U: Berger C. R. \& Roloff M. E. (Eds.), The international encyclopedia of interpersonal communication, Hoboken, NJ: Wiley-Blackwell, 1-4.

Ellison, N., Heino, R. \& Gibbs, J. (2006). Managing Impressions Online: SelfPresentation Processes in the Online Dating Environment, Journal of Computer-Mediated Communication, Volume 11, Issue 2, 415-441.

Gibbs, J., Ellison, N. \& Heino, R. (2006). Self-Presentation in Online Personals. The Role of Anticipated Future Interaction, Self-Disclosure, and Perceived Success in Internet Dating, Communication Research, Vol. 33, Number 2, 152-177.

Goffman, E. (1981). Geschlecht und Werbung, Frankfurt am Main: Suhrkamp.

Goffman, E. (1994). Interaktion und Geschlecht, Frankfurt am Main/New York: Campus Verlag.

Гофман, Е. (2000). Како се представљамо у свакодневном животу [The Presentation of Self in Everyday Life], Београд: Геопоетика.

Гофман, Е. (2009). Стигма: забелешке о опхођену са нарушеним идентитетом [Stigma: Notes on the Management of Spoiled Identity], Novi Sad: Mediterran Publishing.

Heinemann, M. (2000). Textsorten des Alltags. U: Brinker, K., Antos, G., Heinemann W., Sager, S. (Hrsg.): Text- und Gesprächslinguistik. Ein internationales Handbuch zeitgenössischer Forschung, Berlin - New York: Walter de Gruyter, 604-614.

Hofstede, G. (2001). Culture's Consequences: Comparing Values, Behaviors, Institutions, and Organizations Across Nations, 2nd Edition, Thousand Oaks, CA: Sage Publications. 
House, R. J., Hanges, P. J., Javidan, M., Dorfman, P. \& Gupta, V. (eds.) (2004). Culture, Leadership, and Organizations: The GLOBE Study of 62 Societies, Thousand Oaks: Sage Publications.

Inglehart, R. (1998). Modernisierung und Postmodernisierung. Kultureller, wirtschaftlicher und politischer Wandel in 43 Gesellschaften. Frankfurt/Main, New York: Campus Verlag

Kluckhohn, C. (1951). Values and Value Orientations in the Theory of Action. U: Parsons, T. \& Shils, E. (Eds.), Toward a General Theory of Action, New York: Harper \& Row, 387-433.

Kraemer, M. (1998). Partnersuche und Partnerschaft im deutsch-französischen Vergleich 1913-1993. Eine empirische Analyse zum Wertewandel anhand von Heirats- und Bekanntschaftsanzeigen, Münster/New York/München/Berlin: Waxmann Verlag.

Лазић, М. \& Цвејић, С. (2004). Промене друштвене структуре у Србији: случај блокиране пост-социјалистичке трансформације [Changes in the social structure in Serbia: a blocked case post-socialist transformations]. У: Милић, А. (ур.), Друитвена трансформација и стратегије друштвених група: свакодневица Србије на почетку трећег миленијума (Social Transformation and Strategies of Social Groups: Everyday Life in Serbia at the Beginning of the Third Millennium). Београд: Филозофски факултет

Пантић, Д. (1981). Вредносне оријентације младих у Србији [Value orientations of young people in Serbia]. Београд: Истраживачко-издавачки центар CCO Србије.

Павловић 3. (2006). Вредности у Србији у другом добу модернизма [Values in Serbia in Second Age of Modernity], Социолошки преглед, vol. 40, бр. 2, 247-262.

Рицер, Џ. (2012). Савремена сочиолошка теорија и њени класични корени [Contemporary sociological theory and its classical roots]. Београд: Службени гласник.

Riemann, V. (1999). Kontaktanzeigen im Wandel der Zeit. Eine Inhaltsanalyse, Opladen/Wiesbaden: Westdeutscher Verlag.

Schmitz, A. (2017). The Structure of Digital Partner Choice. Switzerland: Springer

Schwartz, S. H. (1994). Beyond individualism-collectivism: New cultural dimensions of values. U: Kim, H. C., Triandis, C., Kagitcibasi, S., Choi, C. \& Yoon G. (Eds.), Individualism and collectivism: Theory, method and applications, Newbury Park, CA: Sage, 77-119.

Schwartz, S. H. (1996). Value Priorities and Behavior: Applying a Theory of Integrated Value Systems. U: Seligman, C., Olson ,J. M., \& Zanna, M. P. (Eds.): The Psychology of Values: The Ontario Symposium, Vol. 8. Hillsdale, NJ: Erlbaum, 1-24.

Schwartz, S. H. (2004). Mapping and interpreting cultural differences around the world, U: Vinken, H., Soeters, J., Ester, P.: Comparing Cultures - Dimensions of Culture in a Comparative Perspective, Leiden: Brill, 43-73.

Skopek, J. (2012). Partnerwahl im Internet. Eine quantitative Analyse von Strukturen und Prozessen der Online-Partnersuche. Wiesbaden: Springer Fachmedien.

Vukonjanski, J., Nikolić, M., Hadžić, O., Terek, E., Nedeljković, M. (2012): Relationship between GLOBE organizational culture dimensions, job satisfaction and leadermember exchange in Serbian organizations. Journal for East European Management studies. Vol. 17, Issue 3, 333-368.

Walther, J. B. (1996). Computer-mediated communication: Impersonal, interpersonal, and hyperpersonal interaction. Communication Research, 23, 3-44.

Whitty, M. T. (2007). Online Matchmaking. New York: Palgrave Macmillan. 


\title{
THE CONCEPT OF THE INDIVIDUAL IN PERSONAL DATING ADS IN PRINT AND ELECTRONIC MEDIA - COMPARATIVE STUDY OF SOCIAL VALUES
}

\author{
Nina Polovina \\ University of Belgrade, Faculty of Transport and Traffic Engineering, \\ Belgrade, Serbia
}

\section{Summary}

Viewing culture as a dynamic phenomenon in the context of an individual's overall social activity, the paper studies the concept of the individual occurring in personal dating ads in Serbian and German media. The initial assumption is that an individual, through creating a personal dating ad, reflects dominant social values. Therefore, a study of these written productions and personal descriptions they contain can lead to relevant conclusions on the society itself.

The subject matter of the present research encompassed personal advertisements published in August and September 2015, 2016 and 2017 in chosen Serbian and German magazines and on two open internet portals. The theoretical background for research involves values in terms of fundamental cultural categories or a unique set of guidelines to the individual which enables her/him to act socially and shape her or his experience of the world. The concept of expectations from a potential partner provides a sound basis for viewing the individuals as formed models of behavior and looks that reflect actual social values.

The paper aims at establishing potential differences in Serbian vs. German personal dating ads as manifestations of values incorporated in respective cultures and compare the female vs. male viewpoints through personal representations of ad authors and their expectations from a partner that are sex-related. A triple methodological procedure is applied to that purpose: contrastive, content and statistical, showing the phenomena frequency of occurrence and tendencies in personal ad discourse development.

In spite of a number of similarities, the analysis evidenced the existence of important differences between the two societies. Personal attitudes and individual behaviour, coupled with the expectations from potential partners proved to be influenced by values prevailing in the relevant environment. According to the research results, the Serbian society finds itself trapped in a gap between tradition and conservativism on the one hand and the aspiration to modernisation and progress on the other. The German society, though, is much more in favour of postmodern values, tolerance and individualisation, while individuals' search for fulfilment of their personal wishes and needs. As far as sexrelated differences are concerned, the image of the ideal man implies, and this is present in both cultures, an individual with a strong character in the first place, while less attention is drawn to his looks. Inversely, women are mainly described by their looks, while personality comes after. When it comes to expectations from male vs. female partners, they differ depending on the cultural background too, thus confirming the initial assumption of the individual representative of prevailing social values. 